\title{
Austrian Experience in RaUmordnung fOr Bulgarian Planning Practice: First Results of a RESEARCH
}

\author{
Ivaylo StaMenkov, Sofia [Sofija]*
}

with 2 tables in the text

\section{Summary}

The article compares spatial planning at the various administrative levels in Austria and Bulgaria with the goal of discovering potentials for knowledge transfer. What strikes most, is the much more decentralised system of spatial planning in Austria in contrast to Bulgaria, where all the competences are in the hands of the central government and just delegated to the lower levels. While in Austria at the federal level just a coordinating body without legislative powers exists, most activities are initiated by the provinces and regions. The article highlights also specifics of the Austrian spatial planning system like the ÖROK-Atlas or the System for Spatial Monitoring. It, however, also acknowledges that a 'copying' of a certain planning culture to another part of Europe may also result in negative effects.

Instead of diminishing, the spatial disproportions in the development of the European Union (EU) have steadily increased over the past few years. The process is more typical for the new member states that joined the EU in and after 2004. That is why the exchange and the usage of experience and methods for the reduction of these disproportions between member states become more and more pressing, especially considering the transfer of knowledge from the highly-developed Western European countries towards the less-developed post-Communist Eastern European countries.

From that point of view the understanding of the Austrian 'spatial planning' system becomes vital for Bulgaria, as on the one hand the Austrian school has an

* Ivaylo Stamenkov, PhD., Sofia University St. Kliment Ochridski, 15 Tzar Osvoboditel Blvd., 1504 Sofija, Bulgaria; email: istamenkov@gea.uni-sofia.bg 
already acknowledged contribution in the development of both theory and practice in this particular field, and on the other both countries are similar in geographical and demographical aspects, while also having identical spatial issues: excessive demographic and economic concentration in the metropolitan agglomeration; less developed peripheral, border, and old industrial regions; as well as regions that depend entirely on the development of a single economic sector (such as tourism, mining and other industries).

Despite the difference in a number of empirical and political elements, terms and practices in the German-speaking space, the Austrian spatial planning traditionally refers to the German planning family. It is even more difficult to speak of a final consensus on the attempt for comparison and classification of the European spatial planning systems, especially those of the European Union, because a considerable part of them do not affect its extensions since 2004. Nevertheless, the German planning tradition is one of the leading in integrating elements of other planning cultures, trying to build a common European model for spatial development. Considering the attempts to study and compare the European planning systems, important contributions came from the German school (continental), the Scandinavian, the British (Anglo-Saxon), the Napoleonic (southern, Mediterranean) and the Eastern (post-Communist).

Bulgaria, as a representative of the Eastern European post-Communist planning family, is still in many aspects in a period of transition. Therefore, the use of the Austrian experience in today's processes of European integration, including the 'Europeanisation' of the Bulgarian planning system, contributes to the relevance of this study. According to the author some of the positive aspects of the Austrian planning system could be easily introduced and applied in Bulgaria, as the process will not imply much time, scientific and economic resources.

Firstly, knowledge of the functioning of the Austrian planning system can contribute to cohesion and coordination between the two fundamentally different types of planning in Bulgaria: technical (Spatial Planning Act) and socio-economic (Regional Development Act).

The main category in Austria is 'spatial organisation' [Raumordnung]. Using different qualities of sub-national dimensional structures, it has a certain alignment or evolving influence. At the same time the category plays an important coordinating role through its superior position in the vertical planning system of Austria on the one hand and on the other in terms of sectoral policies and planning, the financial and economic incentives/stimulations and the conditions of life of individuals, including informal tools and organisations.

At the federal level there is no ministry of similar authority, and the main national organisation, the Austrian Conference on Spatial Planning [Österreichische Raumordnungskonferenz, ÖROK], has coordinating and recommendatory character, while each of the nine provinces [Länder] has a corresponding department. Under 
theoretical aspects, spatial planning [Raumplanung] is considered as part of Raumordnung. In general, spatial planning can be seen in the strict sense (the planning on using a specific territory) and in a broad sense, encompassing the so-called sectorial planning (street planning, delimitation of areas for mining, etc.) (ÖROK 1998).

In Bulgaria there is no term corresponding directly to the meaning of the Austrian Raumordnung. Essential terms in the Bulgarian planning system are spatial planning [устройство на територията] and regional development [регионално развитие]. Spatial planning is defined as "a complex set of activities, which aim to establish rules and relations in the process of organization, exploitation and construction on particular territory. It is an integral part of the socio-economic development of the country and its separate administrative units." (KALINKOV \& Gospodinova 2013) Spatial planning is considered to be an extended and sustained process. It is directed to the reproduction of the environment and regards the three central groups of elements that describe the human existence in the socium: life, work, leisure. This term relays on multiple principles: democracy, complexness, permanence, normativity, balance, continuity, information, etc. Spatial planning creates a territorial base for all processes of sustainable development.

As per Article 2 of the Regional Development Law government policy for regional development should "create conditions for a balanced and sustainable integrated development of the regions and the municipalities and contains a system of normatively regulated documents, resources and actions of the competent authorities" aiming to reduce the differences both in and between the regions in terms of social, economic and territorial development, to support the employment and the cooperation between the Bulgarian regions. As per Article 3 this policy is based on the following principles: common approach for planning and programming, concentration of the resourses, co-financing, coordination between the different authorities, integration with other relevant policies, activities on all levels, partnership, publicity and transparency.

Planning terms are not set in the constitutions of both countries but are defined more precisely in the legislation system of Bulgaria.

Positive for the transformation of the Bulgarian planning system would be the establishment of a national institution like the Austrian Conference on Spatial Planning (ÖROK) aimed to coordinate the measures for the desired spatial development and to award contracts to competent institutions and teams/groups, including geographers. ÖROK, created in 1971, cooperates with the Federation, the provinces, the associations of cities and municipalities in Austria (Austrian Association of Cities and Towns [Österreichischer Städtebund], Austrian Association of Municipalities [Österreichischer Gemeindebund]) and constant economic and social partners. The organisation has no legislative power, but is the only national authority that gives guidelines and coordination; its primary function is to prepare advisory documents. All its decisions are subject to the approval of the Chancellor, all federal ministers, 
governors and presidents of the associations of cities and municipalities in Austria. The most important political decisions are the Austrian Spatial Development Concept [Österreichisches Raumordnungskonzept], recommendations on sectorial issues, national planning documents (e.g. analyses, forecasts, scenarios, etc.), periodic reports on spatial planning, and all these are published in a special book series (ÖROKSchriftenreihe). Among the central tasks of ÖROK is the publication of the "ÖROK -Atlas" (since 1983).

As in a typical unitary state, the planning system in Bulgaria is almost entirely dependent on the national level. An exception is the managing function of municipalities, while regions (corresponding to NUTS-3 regions of the EU) are just an intermediate level for the implementation of the state policy (Tosics et al. 2010). The guiding principles of spatial planning policy are determined by the Council of Ministers. The Minister of Regional Development and Public Works is responsible for its implementation. He coordinates the activities at all levels and exercises control over the overall spatial planning practice through the National Construction Control Directorate. The Minister appoints a National Expert Board on Spatial Planning and Regional Policy, which approves planning documents of national importance. District governors shall implement the national spatial planning policy within the territory of the administrative regions whereof they are in charge. Depending on the spatial planning objectives and tasks of regional and inter-municipality importance the district governor may appoint a regional expert board on spatial planning. Acting within the competence vested therein, the municipal council and the municipality mayor shall implement spatial planning activities within the territory of the relevant municipality. To this level the largest part of spatial planning competences are transferred (PLUREL 2007).

It is necessary for Bulgaria to publish a report similar to the Report on Spatial Planning/RSP [Raumordnungsbericht], a national document that not only focuses on the future, but also analyses the current spatial development. The Reports on Spatial Planning in Austria are some of the main information tools for the spatial planning system. These reports can be prepared at the national (by ÖROK) and regional level (by the relevant departments of the regional governments).

Since its foundation, one of the main activities of ÖROK is to publish periodically national RSPs every three or four years. Their main objective is to analyse the most important spatial and regional developments and to give information for the relevant planning measures. RSP so far is the only proper national document that summarises the spatial trends in Austria, the implementation of the regional policy of the EU and the most important spatial planning measures of the federation, the provinces, cities and municipalities, as well as the economic and social partners of ÖROK.

The so far published 13 national RSP follow relatively the same structure: the first main section, Part A [Teil A], is related to the analysis of processes in spatial 
development. Here are presented the framework conditions and trends of this development, an overview of spatial and regional policy is made, including that of the EU and the report on the implementation of the current Austrian Spatial Development Concept. The second section, Part B [Teil B], is devoted to the reports of the members of ÖROK or their partners in order to explain the most important and relevant spatial measures. According to their respective legal basis not all provinces in Austria are obliged to publish regional RSPs. A typical example of regularly publishing a regional RSP today is Salzburg (since 1977).

A positive aspect of the Austrian planning system that is currently missing in Bulgaria is the publishing of a national atlas of spatial development, the ÖROK-Atlas. It is prepared by ÖROK and it has 30 years of history. It is a central source for spatial monitoring in Austria. Its purpose is to represent many issues of the Raumordnung and the spatial information by producing easily understandable cartographic materials. The problem with it is that many of the maps are not updated and they cannot be used for long-term analyses. Generally the atlas has eight major themes, including several subcategories with respective indicators and an even bigger number of cartographic images: population and households; energy and environment; land use [Flächeninanspruchnahme] and urban development; mobility and accessibility; attractiveness of location [Standortattraktivität] and standard of living; quality of supply [Versorgungsqualität]; economy; topography and administrative boundaries.

In the last two years, in Bulgaria has started an initiative to create a public geographical information system as a part of the Ministry of Regional Development and Public Works. In order to improve the system a project has been approved, implemented with funds of the Operational Programme "Administrative Capacity", co-financed by the EU through the European Social Fund. The aim is to accelerate significantly the visualisation and quality of the available geospatial data, to create operative functionality and the ability to exchange data with existing geographical information systems (GIS). The deadline for implementation of the project is set for the end of 2014. It is expected that all maps to be made up of layers, grouped into themes that can be included/removed for visualisation and are active with the relevant details at a certain scale. The main thematic areas of the maps are: topography, Natura 2000 sites, cadastre, register of landslides and specialised maps. At this stage no cartographic spatial data is presented for a number of demographic and economic spheres.

Another problem for Bulgaria is the lack of a quality system of indicators for monitoring spatial development. Until now only sector-specific monitoring systems are carried out, in which spatial issues are discussed in different form and extent.

This problem is solved in Austria by the decision of 2011 to develop the "System for Spatial Monitoring” [Räumliches Beobachtungssystem für Österreich] that laid the fundament for the introduction of a system of indicators for spatial 
development at national level. In this system of basic principles and objectives of the Austrian Spatial Development Concept 2011 four main categories of monitoring [Beobachtungskategorien] are defined:

- Spatial distribution [Räumliche Verteilung] derived from the principles and objectives of the Austrian Spatial Development Concept 2011 to ensure and improve territorial and social cohesion, positive demographical processes, the provision of regional equivalent living conditions, stimulate rural areas, etc.;

- Spatial relations [Räumliche Beziehungen]: principles and objectives for the development of competitive infrastructure axes, stimulation of functional connectivity, implementation and improvement of supra-regional and regional accessibility, modernisation of telecommunication systems, controlled mechanical population growth as a measure of localisation policy and others;

- Spatial availability and potentials [Räumliche Verfügbarkeit und Potenziale]: principles and objectives of strengthening and disclosure of specific regional potentials, improving competitiveness, enhancing cross-border economic relations, promotion of research and strengthening the innovation capacity of regions, increasing the qualification of the population etc.;

- Spatial carrying capacity [Räumliche Tragfähigkeit]: principles and objectives of sound and sustainable resource development of settlements and open spaces, minimizing the costs of energy and resources, compact settlement structures, reduction of greenhouse gases, replacing non-renewable by renewable resources, etc.

For the study of these four major categories 98 individual indicators grouped into seven "indicator clusters" are offered. Most of the proposed indicators are available and freely accessible and can be found in the ÖROK-Atlas. About one third of them are of limited availability, as most are not planned in ÖROK-Atlas, and only seven of the 98 indicators are planned to be introduced for the first time.

A positive effect for the Bulgarian planning system may be the knowledge of the tools of Austrian spatial planning. The key spatial planning instruments in Austria are set in the local legislation system concerning the so-called Raumordnung and differ from province to province. They could be divided into federal, local, law-binding and non-law-binding. In Bulgaria the spatial planning instruments are defined by the two most relevant for the spatial planning laws. A separate instrument is utilised for every specific administrative level. Traditionally more law-binding are the instruments defined from the Bulgarian Law of Spatial Planning.

More detailed comparison of the planning instruments of both countries shows that there is a coincidence only at national (Both countries publish a national strategy for spatial development.) and municipal level (Master Spatial Plan and Detailed Spatial Plan 
in Bulgaria are comparable with the Austrian Land Use Plan [Flächenwidmungsplan] and Building Plan [Bebauungsplan]) (Table 1 and 2). The Austrian spatial planning instruments in the provinces have different names but similar functions and content. Therefore, we could use as an example the terminology from the province of Lower Austria [Niederösterreich].

Table 1: Spatial planning instruments in Lower Austria including the national level

\begin{tabular}{|l|l|l|}
\hline \multicolumn{1}{|c|}{ Level } & \multicolumn{1}{|c|}{ Instrument (law-binding) } & \multicolumn{1}{c|}{ Instrument (non-low-binding) } \\
\hline $\begin{array}{l}\text { Federation } \\
\text { (NUTS-0) }\end{array}$ & $\begin{array}{l}\text { Various sector-planning } \\
\text { concepts }\end{array}$ & $\begin{array}{l}\text { Austrian Spatial Development Concept } \\
\text { Various sector-planning concepts }\end{array}$ \\
\hline $\begin{array}{l}\text { Province } \\
\text { (NUTS-2) }\end{array}$ & Sector-planning programmes & $\begin{array}{l}\text { Local Development Concept } \\
\text { Various sector-planning concepts }\end{array}$ \\
$\begin{array}{l}\text { Regions } \\
\text { (NUTS-3, 4) }\end{array}$ & $\begin{array}{l}\text { Regional spatial planning } \\
\text { programmes }\end{array}$ & $\begin{array}{l}\text { Micro-regional development concepts } \\
\text { Micro-regional frame concepts }\end{array}$ \\
\hline $\begin{array}{l}\text { Municipality } \\
\text { (LAU-1) }\end{array}$ & $\begin{array}{l}\text { Local programmes for } \\
\text { Raumordnung: }\end{array}$ & $\begin{array}{l}\text { Various sector-planning concepts } \\
\text { (transport, landscape) }\end{array}$ \\
& $\begin{array}{l}\text { Zoning/Land Use Plan } \\
\text { Building Plan }\end{array}$ & \\
&
\end{tabular}

Sources: www.raumordnung-noe.at and Spatial Planning Act of Lower Austria

Table 2: Spatial planning instruments in Bulgaria

\begin{tabular}{|l|l|l|}
\hline \multicolumn{1}{|c|}{ Level } & \multicolumn{1}{|c|}{$\begin{array}{c}\text { Instrument after } \\
\text { Spatial Planning Act }\end{array}$} & \multicolumn{1}{c|}{$\begin{array}{c}\text { Instrument after Regional } \\
\text { Development Act }\end{array}$} \\
\hline \multirow{2}{*}{$\begin{array}{l}\text { National } \\
\text { (NUTS-0) }\end{array}$} & National Concept for Spatial Development 2013-2025 \\
\cline { 2 - 3 } & $\begin{array}{l}\text { National Complex } \\
\text { Spatial Scheme }\end{array}$ & $\begin{array}{l}\text { National Regional Development Strategy } \\
\text { National Development Plan } \\
\text { National Strategic Reference Framework }\end{array}$ \\
\hline $\begin{array}{l}\text { Regional } \\
\text { (NUTS-2) }\end{array}$ & Regional Spatial Scheme & Regional Development Plan \\
\hline District (NUTS-3) & Regional Spatial Scheme & District Development Strategy \\
\hline $\begin{array}{l}\text { Municipality } \\
\text { (LAU-1) }\end{array}$ & $\begin{array}{l}\text { Spatial Master Plan } \\
\text { Detailed Spatial Plan }\end{array}$ & Municipal Development Plan \\
\hline
\end{tabular}

Sources: Spatial Planning Act and Regional Development Act 
Their publication and further connection with the planning of separate national concepts of central places, decentralised concentration, polycentric development and others would be useful for Bulgaria. The recent National Spatial Development Concept for 2013-2025 proposes a 5-stage hierarchy of city-centres, and "the polycentric territorial development" is announced as the second main strategic objective, but these are not published as separate documents. The main task for the concepts of Austrian Spatial Planning is to link the objectives and the guiding principles with the respective instruments and policies, i.e. their operationalisation. The main goal is always the desired result-oriented spatial development. The concepts in Austria can be developed for each of the three main levels of government - federal, provincial and municipial; the most numerous are at the second level. Some of them receive directly instrumentallegal status in the documents for "spatial organisation".

Based on the Austrian experience, it is desirable to publish as well frequent forecasts and scenarios for spatial development. We can find some hints of that in the National Concept for Spatial Development (p. 32), but only from the perspective of urban development. Starting from the baseline condition, which also represents a model in itself, two extremes of urban development - 'extreme monocentrism' and 'extreme polycentrism' - are examined. The study of these two extremes helps, in view of the real opportunities, to determine a model of 'moderate polycentrism', which can be achieved in a foreseeable future within the perspective deadline of the Concept 2025 and be designated as a selected model. In the more distant future, this model will be developed and will get closer stage by stage between 2030 and 2050 towards the model of 'developed polycentrism'.

Last but not least, the Austrian experience can be used in Bulgaria to differentiate sub-regional planning regions (regions for spatial organisation) on the basis of cooperation between municipalities. The reason is that the regionalisation for planning purposes in Austria can be seen in various forms of cooperation between the different spatial units. According to the current $13^{\text {th }}$ Report on Spatial Planning [13. Raumordnungsbericht] 2012 the most important of them are: inter-communal cooperation; cooperation in regional planning; cooperation at regional level; cooperation at supra-district level and cross-border cooperation. Size and boundaries of these regions depend on the purpose and expected results. More important thematic areas for their establishment are: exchange and transfer of knowledge, information and research results; development of harmonized methods and tools (monitoring, statistical data, cartographic bases); developing common strategies, plans, measures (strategies, concepts, etc.); common protection from floods and other natural hazards; general management of enterprises and others.

Similar types are the regions for spatial organisation in Austria, the delimitation/ differentiation of which started with the definition of 'planning regions' in the provinces of Tyrol [Tirol] and Styria [Steiermark]. At national level there is no similar normative 
document for such regionalisation, and also no discussion on the size and shape of such regions. In most cases their boundaries coincide with those of municipalities or political districts and depend on the particular action plan. In the case of the province of Lower Austria these are the informal 'small regions' [Kleinregionen]. Currently, there are 58 and they represent an inter-communal association of varying numbers of municipalities: at least three municipalities with a total population of more than 12,000 people or a minimum of six with a total population of over 8,000 people. The maximum number of municipalities cannot be more than 20 . Their aim is to develop common projects, planning documents or visions for development saving in this way funds and reducing competition.

In Bulgaria inter-communal cooperation is defined by the Constitution (Article 137, Paragraph 1 and 2) and the Law on Local Government and Local Administration (Article 9, Paragraph 1 and Article 59, Paragraph 1 and 2), where the European Charter of Local Self-Government (Article 10, Paragraph 1, 2 and 3) has been considered. In 2004, a concept for a law on inter-municipal cooperation has been developed, but the idea had no adequate institutional support and the law was not adopted.

Legislation for inter-municipal cooperation is not an obstacle for the association of municipalities. It does not prescribe explicit areas (targets) for association or formal rules, but leaves it to the local governments to decide. In general, all inter-municipal initiatives are related to the implementation of specific normative acts and the role of general planning is underestimated. Examples of such initiatives in Bulgaria can be found in the field of waste management, water use, transnational cooperation through Euroregions, tourism and culture. These are the nine Regional Associations of Municipalities and the Local Action Groups (LAGs) under the measure "Communityled local development - Leader" of the Program for Rural Development in the Republic of Bulgaria 2014-2020, the Regional Development Agencies (RDAs) of all regions (NUTS-3), the Bulgarian Cities and Regions Association, and others. The formation of 'planning regions' for inter-communal planning activities becomes increasingly necessary.

In conclusion, the idea of the author is not directly 'to copy' and transfer to Bulgaria these aspects of the Austrian planning system. Such an approach could not only fail in its attempts to improve the current situation, but it is possible to make it worse. What is needed, however, is the exchange of systematic knowledge on planning systems and cultures between the member states of the EU in order to achieve their 'Europeanisation', which can lead to a favourable transfer of knowledge, experience and ideas for overcoming the increasing spatial disparities in Europe. 


\section{References}

Bundeskanzleramt der Republik ÖsterReich (ed.), Raumordnungsgesetz Niederösterreich $<$ https://www.ris.bka.gv.at/Dokumente/LrNo/LRNI_2011090/LRNI_2011090.pdf>

Council of Europe (ed.) (1985), European Charter of Local Self-Government. Strasbourg.

Kalinkov K., Gospodinova A. (2013), Teritorialno ustrojstvo. Varna, Science and economics.

ÖSTERREICHISCHE RAUMORDNUNGSKONFERENZ (ÖROK) (ed.) (1998), Raumordnung in Österreich (= Schriftenreihe der Österreichischen Raumordnungskonferenz, 137). Wien.

ÖSTERREICHISCHE RAUMORDNUNGSKONFERENZ (ÖROK) (ed.) (2008), 12. Raumordnungsbericht. Analysen und Berichte zur räumlichen Entwicklung Österreichs 2005-2007 (= Schriftenreihe der Österreichischen Raumordnungskonferenz, 177). Wien.

ÖSTERREICHISCHE RAUMORDNUNGSKONFERENZ (ÖROK) (ed.) (2011), Österreichisches Raumentwicklungskonzept (ÖREK) 2011 (= Schriftenreihe der Österreichischen Raumordnungskonferenz, 185). Wien.

ÖSTERREICHISCHE RAUMORDNUNGSKONFERENZ (ÖROK) (ed.) (2012a), 13. Raumordnungsbericht. Analysen und Berichte zur räumlichen Entwicklung Österreichs 2008-2011 (= Schriftenreihe der Österreichischen Raumordnungskonferenz, 187). Wien.

ÖSTERREICHISCHE RAUMORDNUNGSKONFERENZ (ÖROK) (ed.) (2012b), Räumliches Beobachtungssystem für Österreich. Inhaltliches Konzept und Umsetzung. Wien.

PLUREL (ed.) (2007), Compendium of Spatial Planning System in the Republic of Bulgaria $<$ www.coe.int/t/dg4/cultureheritage/Source/Policies/CEMAT/CompendiumBG_en.pdf $>$

Republic of Bulgaria (1991), Law on Local Self-government and Local Administration $<$ http://www.lex.bg/bg/laws/ldoc/2132580865>

Republic of Bulgaria (2001), Spatial Planning Act <http://www.lex.bg/laws/ldoc/ 2135163904>

Republic of Bulgaria (2008), Regional Development Act <http://www.lex.bg/bg/laws/ldoc/ 2135589285>

Republic of Bulgaria, National Concept for Spatial Development 2013-2025 <www.bgregio. eu/media/Programirane/NKPR_28012013_Last_en.pdf>

Tosics I. et al. (2010), National spatial planning policies and governance typology <www.plurel. net/images/D221.pdf>

http://gis.mrrb.government.bg/MRRB

http://prsr.government.bg

http://www.abgr.org

http://www.mrrb.government.bg

http://www.oerok.gv.at

http://www.oerok-atlas.at

$\mathrm{http}: / /$ www.raumordnung-noe.at 